\title{
PENGATURAN CITY HOTEL BERKARAKTER CHAIN HOTEL SEBAGAI SALAH SATU BENTUK USAHA JASA PARIWISATA DI INDONESIA (STUDI KASUS DI BALI)
}

Oleh:

Made Suksma Prijandhini Devi Salain ${ }^{1}$

\begin{abstract}
Bali is one of the favorite tourism destinations in the world give benefits as well as loss for Indonesia and Bali particularly. As a tourism place, a lot of Hotels are established in Bali, especially the chain hotels, such as Aston, Ibis, Harris, Fave or Horrison Hotel. Existence of the chain hotels is causing unfair competition with the local hotels. They have different standards in competitive prices. Especially in Bali, there is no regulation that regulates the chain hotels. According to those conditions, it really need to conduct a normative research of the chain hotels regulations within international, national and local Balinese instruments.
\end{abstract}

Keywords: regulations, tourism, chain hotels

\section{PENDAHULUAN}

\subsection{Latar Belakang}

Balimerupakan salah satu tujuan wisata idaman bagi wisatawan domestik maupun mancanegara. Mulai dari tempatnya yang strategis, pemandangan alamnya, budayanya bahkan masyarakatnya yang terbuka menerima kedatangan para wisatawan. Dapat dikatakan Bali merupakan salah satu aset di bidang pariwisata baginegara kita, Indonesia. Untuk itu, masyarakat Bali secara khususnya harus mampu menjaga dan mendukung pariwisata Bali yang berkelanjutan. Apakah itu dimulai dari melestarikan budaya, menjaga kebersihan lingkungan termasuk meningkatkan kualitas tempat penginapan yang dimiliki oleh pelaku bisnis lokal, asing ataupun campuran dari keduanya. Tempat penginapan ini merupakan hal penting bagi para wisatawan yang melakukan perjalanan

Penulis adalah Dosen di Bagian Hukum Internasional Fakultas Hukum Universitas Udayana, email: sukmadevi@gmail.com untuk beristirahat. Mereka membutuhkan tempat yang aman, nyaman dan bersih untuk singgah dan beristirahat. Tempat penginapan di Bali sangatlah beraneka ragam mulai dari yang murah sampai yang mahal, mulai dari rumah penduduk yang disewakan untuk wisatawan sampai hotel yang berkelas internasional. Para wisatawan dengan mudah dapat memilih hotel yang mereka inginkan di Bali melalui internet, travel bahkan langsung menelusuri lokasi hotel yang mereka lihat atau lewati.

Para wisatawan yang datang ke Bali sebagian besar ingin tinggal atau menginap di daerah perkotaan yang memudahkan mereka untuk berpergian kemana-mana. Keadaan inilah yang cepat ditangkap oleh para investor, bagaimana menarik minat wisatawan untuk mau menginap di hotel yang luas bangunannya tidak terlalu besar, pelayanan dan suasananya seperti hotel 5 - star namun harganya reasonable. Para investor lokal maupun asing berlomba- 
lomba untuk membangun hotel di Bali. Sejak tahun 2009 pembangunan hotel di Bali semakin semarak terutama City Hotel dengan manajemen jaringan internasional, seperti Aston, Ibis, Harris, Fave ataupun Horison Hotel. City Hotel di Daerah Kota Denpasar dan Badung sedang menjadi trend, hampir setiap jengkal lahan di Bali didirikan hotel. Pada kenyataannya, bangunan city hotel bermanajemen asing tersebut kebanyakan tidak menggunakan arsitektur tradisional Bali dan harga kamar yang mereka tawarkan cukup murah, misalnya Fave Hotel (2-star) berani memberikan harga yang bersaing dengan Hotel Kelas Melati. Keberadaan city hotel seperti inilah yang membuat keberadaan city hotel yang dimiliki pengusaha lokal terancam. Belum lagi di Gianyar, khususnya Ubud, sudah terdapat paling tidak 2 (dua) city hotel yang masuk ke desa-desa disana sehingga menggeser home stay milik penduduk asli disana dan tentunya dengan harga yang bersaing. Apabila melihat konsep city hotel maka seharusnya hotelnya didirikan di kawasan perkotaan bukan pedesaan, ini berarti ada permasalahan pada pengaturan dan perizinannya. City Hotel bertaraf internasional dengan format "Franchising" yang sering disebut dengan Chain Hotel, seperti "Ibis Hotel" yang menawarkan layanan jasa perhotelan sangat representatif. Hal tersebut tidak sebanding dengan City Hotel lokal yang rata-rata manajemennya dikelola secara lokal. Secara normatif, berdasarkan GeneralAgreementon Tradeand Services (GATS) sebagai salah satu (World TradeOragnization) WTO Agreement, pengelolaan bisnis jasa perhotelan wajib berbasis "Non Discrimination Principle", semua negara anggota diperlakukan sama baik asing maupun lokal, artinya tidak boleh melarang hotel-hotel dari negara anggota WTO didirikan di Bali. Namun permasalahannya, keberadaannya telah mengancam keberlangsungan City Hotel lokal, karena tidak mampu bersaing baik dari segi kualitas prasarana maupun manajemen layanan jasanya. Para pengusaha banyak memilih Aston menjadi mitra bisnis karena Aston sudah memiliki nama besar dan memberikan jaminan keuntungan. Bahkan Charles Brookfield sebagai owner Aston dalam wawancaranya dengan Kompas. com menyatakan bahwa "alasan utama para investor memilih Aston sebagai mitra adalah mereka tahu kami di Aston bekerja keras. Tell me your dream, tell me your vision, kami akan mewujudkannya. Dan Rahasia ada pada service." ${ }^{2}$ Brand hotel-hotel di bawah manajemen Aston Internasional adalah Grand Aston, hotel bintang 5 dengan standar internasional tertinggi sedangkan Royal Kamuela untuk resort mewah bintang 5. Aston adalah brand hotel bintang 4, termasuk serviced apartment dan resort, sementara Kamuela Villas adalah brand bintang 4. Aston memiliki 3 brand di kelas bintang 3, yaitu Aston City, Aston Inn dan Quest. Sementara di kelas Bintang 2 brandnya adalah Fave hotel. ${ }^{3}$

Selain Aston manajemen masih banyak manajemen hotel asing lain, seperti Archipelago Hotel, Shangrilla dan Hyatt yang digunakan oleh para investor bisnis hotel. Pemilik city hotel yang menggunakan manajemen hotel jaringan internasional biasanya adalah investor lokal namun tidak memiliki skill manajemen perhotelan dan

Charles Brookfield : Aston Bangun Hotel di Setiap Kota www.kompas.com Properti htm, diunduh pada 25 Februari 2015

Ibid. 
networking yang cukup sehingga mereka memilihuntukmembelifranchise manajemen hotel jaringan internasional. ${ }^{4}$ Penggunaan manajemen hotel jaringan internasional ini tentunya harus dituangkan dalam bentuk kontrak licence, franchise, manajemen dan bantuan teknik lainnya. ${ }^{5}$

Dari segi ekonomi, keberadaan City Hotel dengan manajemen jaringan internasional

tidak dapat dipungkiri unggul dari segala aspek, mulai dari manajemen, standar fasilitas dan pelayanan bahkan harga yang bersaing namun tidak dari segi hukum. Peraturan perundang-undangan yang mengatur City Hotel dengan karakter Chain Hotel atau menggunakan format franchising tidaklah jelas dan tegas terlebih dengan adanya otonomi daerah, masingmasing daerah memiliki kebijakan yang berbeda-beda. Seperti di Bali, usaha hotel yang menggunakan fasilitas modal asing, apakah itu dari sahamnya ataupun sistem manajemennya hanya dapat dilakukan di kawasan pariwisata menurut Rencana Tata Ruang Wilayah (RTRW) Bali.

Pada kenyataannya City HotelCity Hotel yang didirikan di Daerah Kota Denpasar bukanlah pada kawasan pariwisata, seperti Fave Hotel di Jalan Teuku Umar, Pop Harris di Jalan Teuku Umar, All Season di Jalan Teuku Umar dan Aston di Jalan Gatot Subroto. Bahkan Fave Hotel, All Season dan Pop Harris hanya berjarak 200 - 300 meter. Selain itu, syarat minimal luas tanah untuk mendirikan sebuah hotel pun tidak jelas. Jika

Blanket Agreement (Perjanjian Induk); Blanket Agreement on Hotel Management, http://roninazra. blogspot.com/2012/05/blanket-agreement-perjanjianinduk.html,diunggah pada tanggal 23 Februari 2015 Ibid. melihat luas tanah atau areal City Hotel yang telah disebutkan sebelumnya tidaklah begitu besar sehingga kurangnya lahan parkir yang mengakibatkan kemacetan di Jalan Teuku Umar. Dari segi bangunan atau gedung City Hotel yang ada di Jalan Teuku Umar tersebut sama sekali tidak mencirikan budaya bali menggunakan arsitektur tradisional Bali tetapi cenderung menggunakan arsitektur modern minimalis. Kenyataan ini tentunya menjadi sebuah pertanyaan besar mengapa City Hotel tersebut bisa berdiri dan beroperasi padahal keberadaannya tidak diatur secara jelas dalam peraturan daerah maupun surat keputusan kepala daerah. Pemerintah Provinsi Bali sesungguhnya sudah memberikan peringatan (moratorium) atau penghentian sementara pemberian izin pendirian atau pembangunan hotel pada awal tahun 2011 di Kawasan Bali Selatan, yaitu Kabupaten Badung, Gianyar dan Kota Denpasar. Padatnya pembangunan akomodasi wisata di kawasan itu tak jarang mengabaikan tata ruang, sehingga pemerintah provinsi mengimbau pemerintah daerah untuk mematuhi kebijakan tersebut. ${ }^{6}$

Selainmasalahyang telah dikemukakan diatas, keberadaan prinsip non discrimination dari GATS pada kenyataannya menimbulkan persaingan usaha tidak sehat (unfair trade practices) karena di satu sisi Pemerintah Indonesia tidak boleh dan tidak bisa untuk melarang masuknya investasi asing ke dalam negeri tapi pada akhirnya city hotel dengan format manajemen franshise asing memberikan harga yang bersaing dengan city hotel lokal. Keadaan ini tentu saja mematikan pangsa pasar city hotel lokal

www.republika.co.id,PemprovBali Imbau Moratorium Hotel, Kamis, 13 September 2012, diunduh tanggal 25 Februari 2015 
karena konsumen, dalam hal ini wisatawan pasti akan memilih city hotel dengan format manajemen hotel franchising asing yang berstandar internasional namun harganya reasonable.

Dengan demikian dapat dikatakan bahwa kompleksnya masalah yang ditimbulkan oleh keberadaan city hotel dengan karakter chain hotel / format manajemen franchise asing disebabkan oleh norma yang tidak progresif terhadap perkembangan keadaan masyarakat sehingga menimbulkan ketidakjelasan peraturan perundang-undangan yang terkait (unclear norm). Oleh karena itu diperlukan suatu konstruksi hukum mengenai pendirian city hotel baik lokal maupun asing yang bisa memberikan kesejahteraan, keadilan, kepastian hukum dan kemanfaatan bagi semua pihak.

\subsection{Rumusan Masalah}

1. Bagaimanakah bentuk perwujudan Non-Discrimination Principle dalam GATS sebagai salah satu instrumen WTO terkait dengan city hotel berkarakter chain hotel yang termasuk jasa pariwisata di Indonesia?

2. Bagaimanakah pengaturan jasa pariwisata terkait city hotel dengan karakter chain hotel di Indonesia?

\section{Hasil dan Pembahasan}

2.1 Bentuk perwujudan Non-

Discrimination Principle dalam

GATS sebagai salah satu instrumen WTO terkait dengan city hotel berkarakter chain hotel yang termasuk jasa pariwisata di Indonesia adalah:

\subsubsection{Prinsip Non Diskriminasi (Non- Discrimination Principle) dalam WTO}

Non-Discrimination Principle adalah salah satu sumber hukum internasional dalam bentuk general principles of law (prinsip-prinsip hukum umum yang diakui oleh bangsa beradab). Prinsip-prinsip hukum umum ini dianut oleh seluruh Negara-negara di dunia meskipun memiliki sistem hukum yang berbeda. Keberadaan prinsip hukum umum ini sangat penting jika dilihat dari fungsinya begitu juga dengan Prinsip Non Diskriminasi ${ }^{7}$. Prinsip non diskriminasi ini mengandung pengertian bahwa tidak ada perlakuan yang berbeda terhadap suatu subyek atau obyek hukum, semua mendapatkan perlakuan yang sama tanpa memperhatikan perbedaan ras, suku, agama, umur, kewarganegaraan ataupun disabilitasnya.

Prinsip non diskriminasi menjadi prinsip utama dalam penyelenggaraan perdagangan internasional yang bersifat multilateral di bawah WTO. Ini adalah kunci utama agar perdagangan internasional diantara Negara anggota WTO berjalan

Discrimination is the effect of law or established practice that confers privileges on a certain class or that denies privileges to a certain class because of race, age, sex, nationality, religion or handicap, Lihat Black's Law Dictionary, 2004, Eight Edition, Thomson, West, Amerika Serikat, hlm.500. 
dengan lancar. Di dalam GATS sebagai slaah satu instrumen WTO, Non-Discrimination Principle diwujudkan dalam 2 (dua) bentuk kewajiban, yaitu: the most-favoured nation (MFN) treatment ${ }^{8}$ dan the national treatment $^{9}$ (NT). MFN mensyaratkan Negara anggota WTO (misalkan Indonesia) harus memberikan perlakuan yang sama kepada mitra-mitra dagangnya yang juga merupakan Negara anggota WTO (misalkan Jepang, Brazil, Australia, AMerika Serikat). Sedangkan NT mensyaratkan Negara anggota WTO untuk memperlakukan produk asing yang masuk ke dalam wilayah Negara tersebut sama dengan produk lokalnya (apakah dari segi pajak dan regulasinya).

\subsubsection{City Hotel berkarakter chain hotel sebagai salah satu bentuk perdagangan jasa pariwisata}

GATS adalah agreement di bidang perdagangan jasa internasional. Perdagangan jasa (trade in services) adalah perdagangan yang menempatkan jasa sebagai komoditi. Dalam pengertian perdagangan, jasa mencakup seluruh aktivitas atau usaha yang

The MFN treatment obligation requires a WTO member that grants certain favourable treatment to another country to grant that same favourable treatment to all other WTO members. A WTO member is a not allowed to discriminate between its trading partners. Lihat Peter Van Den Bossche, 2008, The Law and Policy of the World Trade Organization Text, Cases and Materials, Second Edition, Cambridge University Press, New York, hlm.38.

$9 \quad$ The national treatment obligation requires a WTO Member to treat foreign product, services suppliers no less favourably that it treats 'like' domestic products, services and service suppliers. Where the national treatment obligation applies, foreign products, for example, should once they have crossed the border and entered the domestic market, not be subject to less favourable taxation or regulation than 'like' domestic product. Purusuant to the national treatment obligation, a WTO Member is not allowed to discriminate against foreign products, services and service suppliers. Lihat Peter Van Den Bossche, Ibid. diorganisir, secara kualitas, kuantitas, dan jangka waktu tertentu, untuk membantu seseorang atau lebih, mendapatkan keinginannya, berdasarkan proses transaksi, dan imbalan tertentu (services charge). Pengertian yang demikian mencakup pengertian jasa pariwisata, yaitu suatu kegiatan penyediaan jasa akomodasi, makanan, transportasi dan rekreasi, serta jasa lainnya yang terkait ${ }^{10}$.

Hotel merupakan salah satu bentuk jasa akomodasi yang menunjang penyelenggaraan dan pembangunan pariwisata. Oleh karena itu hotel menjadi salah satu obyek pengaturan dari GATS yang menjunjung kewajiban MFN dan NT. Hal ini diatur dalam Pasal 1 Ayat (2) GATS yang menyebutkan 4 (empat) modes supply of services ${ }^{11}$. Dari keempat jenis penyediaan jasa tersebut, jasa perhotelan (city hotel berkarakter chain hotel) termasuk jenis yang ketiga, yakni cara pemberian jasa melalui kehadiran secara komersial (commercial presence mode of supply), dimana pemberi jasa hadir di negara penerima jasa ${ }^{12}$. Sebagai contoh, ASTON, Shangrilla, Ibis dan lainnya. Dengan begitu, para investor diberikan kesempatan untuk mendirikan city hotel berkarakter chain hotel di suatu Negara dengan tetap mendapatkan perlakuan yang

10 Ida Bagus Wyasa Putra, dkk., 2003, Hukum Bisnis Pariwisata, Penerbit Refika Aditama, Bandung, hlm.1

11 (a) from the territory of one Member into the territory of any othe Member; (b) in the territory of one Member to the service consumer of any other Member; (c) by a service supplier of one Member, through commercial presence in the territory of any other Member; (d) by a service supplier of one Member, through presence of natural persons of a Member in the territory of any other Member.

12 Peter van den Bossche, dkk., 2010, Pengantar Hukum WTO (World Trade Organization), Yayasan Obor Indonesia, Jakarta, hlm.15. 
sama seperti chain hotel lainnya termasuk perlakuan yang sama dengan hotel lokal di wilayah Negara tersebut. Namun keadaan yang demikian menimbulkan iklim usaha yang tidak sehat karena city hotel berkarakter chain hotel bermanajemen asing, standar pelayanan internasional memberikan harga yang sama dengan hotel-hotel lokal (tentunya dari segi manajemen dan standar pelayanan masih kurang. Keadaan inilah yang terjadi di Indonesia, khususnya Bali sebagai destinasi pariwisata favorit dunia. Untuk itu sebaiknya perlu diuraikan bagaimana sesungguhnya implementasi dari prinsip non diskriminasi (yang melahirkan kewajiban MFN dan NT) dalam perdagangan jasa pariwisata khususnya city hotel berkarakter chain hotels.

\subsubsection{MFN dalam GATS}

MFN pada perdagangan jasa diatur dalam Pasal II : 1 GATS : "With respect to any measure covered by this Agreement, each Member shall accord immediately and unconditionally to service and service suppliers of any other Member treatment no less favourable than that it accords to like services and service suppliers of any other country"'13. Jadi, kewajiban MFN harus ditaati dan dilaksanakan oleh seluruh Negara anggota WTO secara segera dan tanpa persyaratan. Ada 3 (tiga) pertanyaan yang harus dipenuhi untuk menentukan apakah sebuah ketentuan dari salah satu Negara anggota WTO inconsistency terhadap kewajiban MFN sesuai Pasal II : 1 GATS, yaitu ${ }^{14}$ :

Garis bawah ditambahkan oleh penulis.

Peter van den Bossche,dkk., Ibid., hlm.13 i. apakah GATS dapat diterapkan terhadap ketentuan tersebut;

ii. apakah jasa atau pemberi jasa adalah jasa sejenis atau pemberi jasa sejenis; dan

iii. apakah jasa atau pemberi jasa dari anggotaWTOlainnyamenerima, secara segera dan tanpa syarat, perlakuan yang tidak kurang menguntungkan dari jasa sejenis dan pemberi jasa sejenis dari Negara lainnya.

Meskipun pemberlakuan kewajiban MFN immediately dan unconditionally, berdasarkan Pasal II : 2 GATS diperbolehkan adanya pengecualian: $A$ Member may maintain a measure inconsistent with paragraph 1 provided that such a measure is listed in, and meets the conditions of, the Annex on Article II Exemptions". Pengecualian pemberlakuan MFN oleh suatu Negara anggota WTO diberikan sepanjang tindakan-tindakannasional tertentudimaksud sudah didaftarkan dan didaftarkan dalam Lampiran Perkecualian-perkecualian Pasal II : 2 GATS. Pengecualian yang didaftarkan oleh Negara anggota WTO harus berisikan: " a description of the sectors in which the exemption applies; a description of the measure, indicating whyit is inconsistent with Article II; the country or countries to which the measure applies; the intended duration of the exemption; and the conditions creating the need for the exemption ${ }^{15}$. Pengecualian ini pada awalnya harus didaftarkan sampai dengan mulai berlakunya WTO, 1 Januari 1995 dan berakhir pada Januari 2005. Namun pada kenyataannya, Negara anggota WTO masih menggunakan pengecualian ini

15 Peter Van Den Bossche, op.cit., hlm.342. 
sampai dengan sekarang dengan jangka lebih dari 5 tahun dan di-review oleh Council for Trade in Services ${ }^{16}$.

\subsubsection{NT dalam GATS}

Pasal XVII GATS mengatur tentang National Treatment (NT) : "In the sectors inscribed in its Schedule, and subject to any conditions an qualifications set out therein, each Member shall accord to services and service suppliers of any other Member, in respect of all measures affecting the supply of services, treatment no less favourable than that it accords to ${ }^{17}$ its own like services and service suppliers". Tidak semua services and service suppliers mendapatkan perlakuan nasional jadi hanya sektor-sektor jasa tertentu yang dituangkan dalam komitmen ( Schedule of Specific Commitments). Negara anggota WTO diberikan kebebasan untuk membuat komitmen atau tidak. Pembuatan komitmen perlakuan nasional (NT) berdasarkan negosiasi dari para Negara anggota WTO. Jadi, sesungguhnya kewajiban NT ini dikembalikan lagi kepada masing-masing anggota WTO karena mereka memiliki kemampuan dan kebutuhan ekonomi yang berbeda satu dengan lainnya. Meskipun demikian, bisa saja anggota WTO yang sudah membuat komitmen NT tersebut melanggar / inconsistency kewajiban NT tersebut dan untuk membuktikannya harus memenuhi 3 (tiga) pertanyaan / tes:

i. apakah GATS dapat diterapkan pada aturan yang dipermasalahkan;

ii. apakah jasa atau pemberi jasa asing dan domestic adalah 'jasa sejenis' atau'pemberi ajasa sejenis' dan;

Lihat Annex on Article II Exemptions GATS Peter van den Bossche, dkk., op.cit., hlm.24. iii. apakah jasa dan 'pemberi jasa asing' mendapat perlakuan yan kurang menguntungkan dibandingkan dengan jasa dan pemebri jasa domestik.

\subsubsection{Daftar Pengecualian kewajiban MFN dan NT terkait city hotel berkarakter chain hotel sebagai salah satu bentuk jasa pariwisata di Indonesia}

Dengan melihat uraian kewajiban MFN dan NT dalam GATS diatas, sesungguhnya Indonesia sudah mengimplementasikan prinsipnon diskriminasi dengan baik terutama pada perdagangan jasa city hotel berkarakter chain hotel. Hal ini terbukti dari banyaknya city hotels yang dimiliki investor asing atau menggunakan manajemen franchise asing yang tumbuh dan berkembang di Indonesia, khususnya Bali. Namun keberadaan city hotel berkarakter chain hotel bukannya menciptakan iklim persaingan usaha yang sehat tetapi mematikan pangsa pasar city hotel lokal. Kenyataan ini menujukkan bahwa liberalisasi perdagangan jasa bagaikan 2 (sisi) mata uang, memberikan keuntungan sekaligus kerugian bagi keadaan ekonomi masyarakat Bali khususnya dan Indonesia pada umumnya.

Seperti yang telah disebutkan diatas, diperbolehkan adanya pengecualian terhadap kewajiban MFN dan NT di dalam GATS. Seharusnya Pemerintah Indonesia dapat memanfaatkan pengecualian tersebut demi menyelamatkan perkembangan ekonomi masyarakatnya. Namun pada kenyataannya, berdasarkan Indonesia Final List of Article II (MFN) Exemptions tanggal 15 April 1994 dan 28 Juli 1995, hanya ada 3 (tiga) sector yang didaftarkan, yakni Banking Services, Construction Services dan Movement of 
personal (semi-skilled workers). Daftar pengecualian kewajiban MFN terakhir yang didaftarkan Indonesia adalah tahun 1995 sedangkan sekarang sudah tahun 2015, tentunya sangat banyak perubahan yang terjadi pada perdagangan jasa pariwisata khususnya terkait city hotel berkarakter chain hotel. Sedangkan pengecualian kewajiban NT dalam bentuk komitmen khusus (specific commitments), Indonesia sudah mendaftarkannya sejak 15 April 1994 kemudian ada beberapa suplemen didaftarkan pada 28 Juli 1995, 11 April 1997 dan 26 Februari 1998. Hal yang sama terjadi pada MFN List of Exemption, pengecualian kewajiban NT yang berkaitan dengan tourism services (termasuk hotel) hanya didaftarkan pada tahun 1994:

i. Limitation on Market access : In eastern part of Indonesia, Kalimantan, Bengkulu, Jambi and Sulawesi, 100\% of capital share can be owned by foreign investor.

ii. Limitations on National Treatment : (a) Higher paid-up capital is required of foreign service suppliers than of domestic service suppliers. This measure will be eliminate in the year 2020; (b) only 3, 4, 5 starred hotels are permitted.

Pengecualian kewajiban NT yang berkaitan dengan hotel sudah tidak sesuai dengan pertumbuhan hotel yang ada di Indonesia, khususnya Bali sehingga tidak mampu melindungi keberadaan city hotel lokal yang diserbu oleh city hotel berkarakter chain hotels. Pada zaman itu belum muncul city hotel berkarakter chain hotel, yang ada pada saat itu hanya hotel berbintang dengan harga yang jauh lebih mahal dari hotel lokal sehingga iklim persaingan usahanya lebih sehat (kompetitif).

\subsection{Pengaturan jasa pariwisata terkait city hotel dengan karakter chain hotel di Indonesia}

Pengaturan jasa pariwisata di Indonesia belum dapat berfungsi dengan baik dan mencapai tujuan hukum yang seharusnya. Hal ini disebabkan oleh kompleksnya problem yang terjadi pada payung hukum pariwisata di Indonesia, yaitu Undang-Undang No. 10 Tahun 2009 tentang Kepariwisataan ${ }^{18}$. Selain UU Kepariwisataan, ada beberapa peraturan perundang-undangan yang terkait dengan jasa pariwisata khususnya mengenai hotel, seperti Undang-Undang No. 5 Tahun 1999 tentang Larangan Praktek Monopoli dan Persaingan Usaha Tidak Sehat, UndangUndang No. 25 Tahun 2007 tentang Penanaman Modal, Undang-Undang No. 40 Tahun 2007 tentang Perseroan Terbatas dan Peraturan Daerah terkait. Berikut adalah pembahasan mengenai beberapa peraturan perundang-undangan yang telah disebutkan diatas.

\subsubsection{Undang-Undang No. 10 Tahun 2009 tentang Kepariwisataan}

UU Kepariwisataan ini banyak sekali mengandung problem di dalamnya, mulai dari problem definisi, problem konsep, problem norma hingga problem pengaturannya. Akar permasalahannya adalah istilah kepariwisataan yang diatur dalam Pasal 1 Ayat (4) adalah keseluruhan kegiatan terkait dengan pariwisata dan bersifat multidimensi serta multidisiplin yang muncul sebagai wujud kebutuhan

18 Selanjutnya disebut UU Kepariwisataan 
setiap orang dan Negara serta interaksi antara wisatawan dan masyarakat setempat, sesama wisatawan, Pemerintah, Pemerintah Daerah dan pengusaha. Definisi kepariwisataan ini tidak sesuai dengan karakteristik pariwisata pada saat sekarang ini, yaitu perdagangan jasa (tourism is a trade in services). Dengan menggunakan policy-oriented theory of law, permasalahan / problem yang timbul dalam UU Kepariwisataan terjadi pada tahap meso analyses, a problem of wrong on defining or perhaps the vacuum on defining the objects which become a problem definition ${ }^{19}$. Ketepatan dalam mendefinisikan suatu obyek pengaturan merupakan hal yang sangat penting dalam proses pembuatan hukum dan kebijakan.

UU Kepariwisataan mengusung konsep pariwisata sebagai pembangunan yang mengacu pada Global Code of Ethics of Tourism yang dibuat oleh World Tourism Organization. Di satu sisi, pembentukan UU Kepariwisataan adalah upaya harmonisasi ketentuan GATS ke dalam hukum nasional Indonesia. Konsep pariwisata dalam GATS adalah perdagangan jasa. Hal ini menunjukkan terjadinya problem konsep pariwisata di dalam UU Kepariwisataan. Di saat penyelenggaran dan pembangunan pariwisata dunia menggunakan konsep pariwisata sebagai perdagangan jasa, Indonesia malah tetap di tempat dengan menggunakan konsep pembangunan pariwisata yang sudah lama ditinggalkan. Keadaan ini disebut sebagai normative-

Wayne Parson, 2005, Public Policy, hlm. 87 dalam Ida Bagus Wyasa Putra, 2013, Indonesian Tourism Law : In Search of Law and Regulations Model, Lex Mercatoria, Journal of International Trade and Business Law, Vol.1 Number 1, The Role of Law and Policy in Promoting National and Regional Economic Development, hlm.62. ambiguity". "By this mean that such theory seeks in a single confused statement to perform multiple intellectual tasks. Thus, the ordinary legal rule or concept seeks, at one and the same time, to describe what decision-makers have done in the past, to predict what they will do in the future, and to prescribe what they ought to do" ${ }^{21}$.

Problem konsep yang terjadi dalam UU Kepariwisataan tentunya akan menimbulkan problem pengaturan karena materi yang diatur tidak sesuai dengan kegiatan pariwisata dalam kenyataan sehingga menyebabkan tidak berfungsinya dengan baik UU tersebut. "The huge number of laws has not followed by an actual controlling effect over the performance of tourism, including the business and its detrimental impacts to the business and its environment. Tourism activities are loaded with unfair trade practices such as tariff war and irrational services supply in most of tourism business centers" ${ }^{22}$

City hotel dengan karakter chain hotel merupakan salah satu usaha jasa pariwisata di Indonesia. Hal ini diatur dalam Pasal 14 Ayat (1) UU Kepariwisataan: (a) daya tarik wisata; (b) kawan pariwisata; (c) jasa transportasi wisata; (d) jasa perjalanan wisata; (e) jasa makanan dan minuman; (f) penyediaan akomodasi; (g) penyelenggaran kegiatan hiburan dan rekreasi; (h) penyelenggaraan pertemuan, perjalanan insentif, konferensi dan pameran; (i) jasa informasi pariwisata;

20 Laswell and McDougal, 1943, Legal Education and Public Policy: Professional Training in the Public Interest, 52 Yale L.J. 203, 208-209 dalam Myres S. McDougal, 1956, Law as a Process of Decision : A Policy-Oriented Approach to Legal Study, Yale Law School Lagal Scholarship Repository, hlm.59, diunduh pada 25 Februari 2015

Myres S. McDougal, Ibid.

22 Ida Bagus Wyasa Putra, loc.cit., hlm.62. 
(j) jasa konsultan pariwisata; (k) jasa pramuwisata; (1) wisata tirta; dan (m) spa). Hotel digolongkan sebagai salah satu jasa akomodasi.

\subsubsection{Undang-Undang No. 5 Tahun 1999 tentang Larangan Praktek Monopoli dan Persaingan Usaha Tidak Sehat \\ Pertumbuhan city hotel berkarakter} chain hotel di Indonesia, khususnya Bali menimbulkan iklim persaingan usaha yang tidak sehat. City hotel berkarakter chain hotel dengan standar dan fasilitas internasional namun memberikan harga lokal kepada para konsumennya. Sudah tentu wisatawan akan memilih city hotel berkarakter chain hotel daripada city hotel lokal dengan harga yang bersaing namun kualitas pelayanannya berstandar internasional. Keadaan ini sesungguhnya dilarang dalam Pasal 21 Undang-Undang No. 5 Tahun 1999 tentang Larangan Praktek Monopoli dan Persaingan Usaha Tidak Sehat : "Pelaku Usaha dilarang melakukan kecurangan dalam menetapkan biaya produksi dan biaya lainnya yang menjadi bagian dari komponen harga barang dan atau jasa yang dapat mengakibatkan terjadinya persaingan usaha tidak sehat".

\subsubsection{Undang-Undang No. 25 Tahun 2007} tentang Penanaman Modal

a) Pendirian City hotel berkarakter chain hotel di Indonesia haruslah dalam bentuk Perseroan Terbatas (PT). Hal ini diatur dalam Pasal 5 Ayat (2) UU Penanaman Modal : "Penanaman modal asing wajib dalam bentuk perseroan terbatas berdasarkan hukum Indonesia dan berkedudukan di dalam wilayah negara Republik Indonesia, kecuali ditentukan lain oleh undang- undang". Modal yang ditanamkan oleh investor asing di Indonesia dapat berupa aset dalam bentuk uang atau bentuk lain yang bukan uang yang dimiliki oleh penanam modal yang mempunyai nilai ekonomis ${ }^{23}$.

b) UU Penanaman Modal juga mengatur mengenai kewajiban MFN dan NT yang tertuang dalam Pasal 6:

(1) Pemerintah memberikan perlakuan yang sama kepada semua penanam modal yang berasal dari negara mana pun yang melakukan kegiatan penanaman modal di Indonesia sesuai dengan ketentuan peraturan perundang-undangan.

(2) Perlakuan sebagaimana dimaksud pada ayat (1) tidak berlaku bagi penanam modal dari suatu negara yang memperoleh hak istimewa berdasarkan perjanjian dengan Indonesia.

Pasal ini menunjukkan bahwa Indonesia sebagai salah satu Negara anggota WTO sudah mengimplementasikan NonDiscrimination Principle (MFN dan NT) ke dalam hukum nasionalnya.

\subsubsection{Beberapa Peraturan Daerah yang} terkait (studi kasus di Daerah Provinsi Bali)

a) Pasal 5 Ayat (3) Peraturan daerah (Perda) Provinsi Bali No.2 Tahun 2012 tentang Kepariwisataan Budaya Bali menyatakan:

"Pembangunan Sarana dan prasarana kepariwisataan dengan menggunakan fasilitas modal asing hanya dapat

Lihat Pasal 1 Ayat (7) UU Penanaman Modal 
dilakukan di kawasan pariwisata yang telah ditetapkan dalam Rencana Tata Ruang Wilayah Provinsi Bali.”

b) Pasal 1 Angka 55 Perda Provinsi Bali No. 16 Tahun 2009 tentang Rencana Tata Ruang Wilayah Provinsi Bali Tahun 2009-2029 :

"Kawasan Pariwisata adalah kawasan strategis pariwisata yang berada dalam geografis satu atau lebih wilayah administrasi desa atau kelurahan yang di dalamnya terdapat potensi daya tarik wisata, aksesibilitas yang tinggi, ketersediaan fasilitas umum dan fasilitas pariwisata serta aktivitas sosial budaya masyrakat yang saling mendukung dalam perwujudan kepariwisataan."

Dengan mengacu pada kedua pasal diatas, dapat ditarik kesimpulan bahwa usaha hotel yang menggunakan fasilitas modal asing, apakah itu dari sahamnya ataupun sistem manajemennya hanya dapat dilakukan di kawasan pariwisata menurut Rencana Tata Ruang Wilayah (RTRW) Bali. Pada kenyataannya City Hotel-City Hotel yang didirikan di Daerah Kota Denpasar bukanlah pada kawasan pariwisata, seperti Fave Hotel di Jalan Teuku Umar, Pop Harris di Jalan Teuku Umar, All Season di Jalan Teuku Umar dan Aston di Jalan Gatot Subroto. Bahkan Fave Hotel, All Season dan Pop Harris hanya berjarak 200 - 300 meter. Selain itu, syarat minimal luas tanah untuk mendirikan sebuah hotel pun tidak jelas. Jika melihat luas tanah atau areal City Hotel yang telah disebutkan sebelumnya tidaklah begitu besar sehingga kurangnya lahan parkir yang mengakibatkan kemacetan di Jalan Teuku Umar. c) Pasal 122 Ayat (2) huruf (g) Perda RTRW Provinsi Bali Tahun 20092029:

"Pengharusan penerapan ciri khas arsitektur tradisional Bali pada setiap bangunan akomodasi dan fasilitas penunjang pariwisata."

d) Penjelasan Pasal 124 Ayat (2) huruf (d) Perda RTRW Provinsi Bali Tahun 2009-2029 : "Persyaratan arsitektur Bali, meliputi antara lain persyaratan penampilan bangunan gedung, tata ruang dalam, keseimbangan, keserasian dan keselarasan bangunan gedung dengan lingkungan serta pertimbangan adanya keseimbangan antara nilainilai sosial budaya setempat terhadap penerapan berbagai perkembangan arsitektur dan budaya".

Bangunan Fave Hotel, All Season, Pop Harris sama sekali tidak mencirikan budaya bali yang menggunakan arsitektur tradisional Bali tetapi cenderung menggunakan arsitektur modern minimalis. Kenyataan ini tentunya menjadi sebuah pertanyaan besar mengapa City Hotel tersebut bisa berdiri dan beroperasi padahal keberadaannya tidak diatur secara jelas dalam peraturan daerah maupun surat keputusan kepala daerah.

\section{Penutup}

\subsection{Simpulan}

a. Non-Discrimination Principle dalam GATS sebagai salah satu instrumen WTO terkait dengan city hotel berkarakter chain hotel yang termasuk jasa pariwisata di Indonesia diwujudkan dalam 2 (dua) bentuk kewajiban, yaitu MFN dan NT. Kewajiban ini merupakan kunci utama terlaksananya 
perdagangan multilateral dalam WTO. Meskipun MFN dan NT merupakan kewajiban mutlak bagi setiap Negara anggota WTO, namun tetap diberikan pengecualianterhadappelaksanaannya. Pengecualian kewajiban MFN dan NT harus dinegosiasikan terlebih dahulu, kemudian didaftarkan dan ada jangka waktunya. Indonesia mendaftarkan pengecualian kewajiban MFN (list of exemption) pada tahun 1994 dan 1995 namun tidak ada memuat mengenai hotel sebagai salah satu bentuk jasa pariwisata. Sedangkan pengecualian kewajiban NT (specific commitments) didaftarkan Indonesia pada tahun 1994, 1995, 1997 dan 1998. Hanya specific commitments yang didaftarkan pada tahun 1994 memuat tentang hotel sebagai salah satu bentuk jasa pariwisata.

b. Pengaturan city hotel dengan karakter chain hotel sebagai salah satu bentuk jasa pariwisata di Indonesia tidak berfungsi dengan baik dan mencapai tujuan hukum yang seharusnya. Hal itu dapat dilihat pada UU Kepariwisataan sebagai payung hukum pariwisata di Indonesia. Penyebabnya adalah kompleksnya problem yang terjadi di dalam UU Kepariwisataan tersebut, baik problem definisi, konsep, norma maupun pengaturannya. Adapun beberapa pengaturan yang terkait, yakni : UU Larangan Praktek Monopoli dan Persaingan Usaha Tidak Sehat, UU Penanaman Modal, UU Perseroan Terbatas dan beberapa Perda Provinsi Bali (karena studi kasusnya di Bali). Beberapa peraturan perundangan tersebut juga tidak dapat berfungsi dengan baik dan mencapai tujuannya. Namun problem bukan timbul dari peraturan tersebut tetapi pelaksanaannya di lapangan.

\subsection{Saran}

a. Untuk ke depannya Indonesia lebih baik untuk merevisi daftar pengecualian kewajiban MFN dan NT yang terkait dengan hotel sebagai salah satu bentuk jasa pariwisata agar dapat melindungi keberadaan city hotel lokal dari serbuan city hotel berkarakter chain hotel yang menyebabkan terjadinya persaingan usaha yang tidak sehat.

b. Pemerintah Indonesia perlu merevisi UU Kepariwisataannya dan bertindak lebih tegas dalam penerapan peraturan perundangan terkait lainnya agar fungsi dan tujuan hukum dapat tercapai.

\section{DAFTAR PUSTAKAI. BUKU}

Ida Bagus Wyasa Putra, dkk., 2003, Hukum Bisnis Pariwisata, Penerbit Refika Aditama, Bandung

Peter Van Den Bossche, 2008, The Law and Policy of the World Trade Organization Text, Cases and Materials, Second

Edition, Cambridge University Press, New York

Peter van den Bossche, dkk., 2010, Pengantar Hukum WTO (World Trade Organization), Yayasan Obor Indonesia, Jakarta

Black's Law Dictionary, 2004, Eight Edition, Thomson, West, Amerika Serikat 
II. JURNAL / ARTIKEL INTERNET Ida Bagus Wyasa Putra, 2013, Indonesian Tourism Law : In Search of Law and Regulations Model, Lex Mercatoria, Journal of International Trade and Business Law, Vol.1 Number 1, The Role of Law and Policy in Promoting National and Regional Economic Development

Charles Brookfield : Aston Bangun Hotel di Setiap Kota, www.Kompas.com Properti.htm, diunduh pada 25 Februari 2015

Blanket Agreement (Perjanjian Induk); Blanket Agreement on Hotel Management, http://roninazra. blogspot.com/2012/05/blanketagreement-perjanjian-induk.html, diunggah pada tanggal 23 Februari 2015

www.republica.co.id, Pemprov Bali Imbau Moratorium Hotel, Kamis, 13 September 2012, diunduh tanggal 25 Februari 2015

Myres S. McDougal, 1956, Law as a Process of Decision : A Policy-Oriented Approach to Legal Study, Yale Law School Lagal Scholarship Repository, diunduh pada 25 Februari 2015

\section{INSTRUMEN INTERNASIONAL}

World Trade Organization (WTO) Agreement

General Agreement on Trade in Services (GATS)

Global Code of Ethics of Tourism by World Tourism Organization (UN-WTO)
IV. PERATURAN

PERUNDANG-UNDANGAN

Undang-Undang No. 5 Tahun 1999 tentang Larangan Praktek Monopoli dan Persaingan Usaha Tidak Sehat

Undang-Undang No. 10 Tahun 2009 tentang Kepariwisataan

Undang-Undang No. 25 Tahun 2007 tentang Penanaman Modal

Peraturan Daerah Provinsi Bali No. 16 Tahun 2009 tentang Rencana Tata Ruang Wilayah Provinsi Bali Tahun 2009-2029

Peraturan Daerah Provinsi Bali No.2 Tahun 2012 tentang Kepariwisataan Budaya Bali. 